\title{
Membrane localization and $\mathrm{pH}$-dependent transport of a newly cloned organic cation transporter (PMAT) in kidney cells
}

\author{
Li Xia, Karen Engel, Mingyan Zhou, and Joanne Wang \\ Department of Pharmaceutics, University of Washington, Seattle, Washington
}

\begin{abstract}
Plasma membrane monoamine transporter (PMAT) is a novel membrane transporter recently cloned and characterized in our laboratory. We previously demonstrated that PMAT functions as a polyspecific organic cation transporter and efficiently transports many organic cations such as monoamine neurotransmitters and 1-methyl-4-phenylpyridinium $\left(\mathrm{MPP}^{+}\right)$. In this study, we explored the role of PMAT in the renal handling of organic cations. Using a polyclonal antibody generated toward the $\mathrm{NH}_{2}$-terminal 66 amino acid residues of human PMAT, we showed that the PMAT protein $(\sim 55 \mathrm{kDa})$ is expressed in the human kidney and is primarily targeted to the apical membranes when expressed in polarized Madin-Darby canine kidney (MDCK) cells. Using MDCK cells stably expressing human PMAT, we showed that PMAT-mediated MPP ${ }^{+}$uptake is strongly dependent on extracellular $\mathrm{pH}$. Lowering extracellular $\mathrm{pH}$ from 7.4 to 6.6 greatly stimulated PMAT-mediated $\mathrm{MPP}^{+}$uptake, whereas elevating extracellular $\mathrm{pH}$ to 8.2 abolished transporter activity. Kinetic analysis revealed that the apparent $V_{\max }$ at $\mathrm{pH} 6.6$ is about fourfold higher than that at $\mathrm{pH} 7.4$, whereas the apparent $K_{\mathrm{m}}$ values were not statistically different at these two conditions. Under acidic conditions ( $\mathrm{pH}$ 6.6), the proton ionophore, carbonyl cyanide $p$ trifluormethoxyphenylhydrazone, drastically reduced PMAT-mediated $\mathrm{MPP}^{+}$uptake, suggesting that the stimulatory effect of proton may be due to transporter coupling with a proton gradient. Taken together, our data suggest that PMAT is expressed on the apical membranes of renal epithelial cells and may use luminal proton gradient to drive organic cation reabsorption in the kidney.
\end{abstract}

\section{Keywords}

organic cation; $\mathrm{MPP}^{+}$; apical membrane; equilibrative nucleoside transporter 4; monoamine neurotransmitters

\footnotetext{
Many endogenous compounds (e.g., biogenic amines), as well as xenobiotics, including drugs and environmental toxins, carry a net positive charge at physiological $\mathrm{pH}$ and are collectively termed "organic cations". A major route of organic cation elimination is through renal excretion $(14,19,22)$. Renal handling of organic cations is pleiotropic and involves multiple mechanisms. Although secretion generally appears to be the predominant direction of organic cation flux in the kidney, a number of reabsorptive processes have also been described $(12,20,22)$. Recent cloning of a number of transporters involved in the renal handling of organic cations has greatly advanced our understanding of the molecular mechanisms underlying organic cation transport in the kidney.
}

Address for reprint requests and other correspondence: J. Wang, Dept. of Pharmaceutics, Univ. of Washington, H272J, Health Sciences Bldg., Seattle, WA 98195-7610 (e-mail: jowang@u.washington.edu). 
To date, at least four different types of membrane transporters have been recognized in the renal transport of organic cations $(10,13,20)$. The organic cation transporters (OCTs) from the solute carrier 22 (SLC22) family are localized to the basolateral membrane of renal tubular cells, where they mediate $\mathrm{Na}^{+}$-independent, electrogenic uptake of small, hydrophilic organic cations from blood to proximal tubular cells $(6,19)$. In humans, OCT2 is the major isoform responsible for the uptake of organic cations across the basolateral membrane $(6,19)$. At the apical membrane, small, hydrophilic organic cations are excreted into the lumen via an organic cation/proton exchange mechanism, which is mediated by the newly identified mammalian multidrug and toxin extrusion transporter MATE1 (13). Bulkier and more hydrophobic organic cations are excreted at the apical membrane by the multidrug resistance protein MDR1 (ABCB1) $(10,19)$. In addition, two novel organic cation transporters OCTN1/2, which also belong to the SLC22 family, have been found in the kidney. OCTN1 and 2 are localized to the apical membranes, where they may participate in apical transport (secretion or reabsorption) of some organic cations $(10,19,21)$.

Recently, our laboratory cloned a plasma membrane mono-amine transporter (PMAT) from a human kidney cDNA library (5). Although this transporter exhibits significant sequence homology ( $20 \%$ identity) to mammalian equilibrative nucleoside transporters (ENTs, SLC29), we previously demonstrated that PMAT (also termed ENT4) does not typically transport nucleosides and nucleoside analogs. Instead, PMAT is a polyspecific organic cation transporter and exhibits striking functional similarity to the OCTs (4,5). For example, PMAT transports classic OCT substrates, such as 1-methyl-4-phenylpyridinium $\left(\mathrm{MPP}^{+}\right)$, tetraethylammonium (TEA), and monoamine neurotransmitters $(4,5)$. Prototype OCT inhibitors, including decynium-22, cimetidine, and type II cations (e.g., quinidine, quinine) are also PMAT inhibitors. Like the OCTs, PMAT-mediated organic cation transport is $\mathrm{Na}^{+}$independent and electrogenic (5). In humans, Northern blot analysis revealed that mRNA transcripts of PMAT are most abundantly expressed in the brain, where it may play a role in the clearance of monoamine neurotransmitters $(5,23)$. In addition to the brain, mRNA transcripts of PMAT are also found in several other organs, including the kidney (5), but the role of this transporter in the renal transport of organic cation is unknown. In the present study, we developed a PMAT-specific antibody and provided biochemical evidence that PMAT protein is present in the human kidney, and the transporter is likely to be localized on the apical membranes of renal epithelial cells. We also demonstrated that PMAT-mediated organic cation uptake is greatly stimulated by acidic $\mathrm{pH}$ and the transporter may use luminal proton gradient as a driving force to energize organic cation transport.

\section{MATERIALS AND METHODS}

\section{Materials}

$\left[{ }^{3} \mathrm{H}\right] \mathrm{MPP}^{+}(80 \mathrm{Ci} / \mathrm{mmol})$ was purchased from American Radiolabeled Chemicals (St. Louis, MO). 2'-Deoxytubercidin was purchased from Berry \& Associates (Ann Arbor, MI). All other chemicals were obtained from Sigma (St. Louis, MO) and were of analytic grade.

\section{Construction, expression, and purification of a glutathione S-transferase -PMAT $\mathrm{NH}_{2}$ - terminal fusion protein}

A 219-bp BamHI-EcoRI cDNA fragment encoding the $\mathrm{NH}_{2}$-terminal 66 amino acid residues of human PMAT was generated by PCR from PMAT cDNA cloned from a human kidney cDNA library (5). The fragment was subcloned into the pGEX-2T plasmid in frame to the $\mathrm{COOH}$ terminus of Schistosoma japonicum glutathione $S$-transferase (GST) under the control of a lactose-inducible tac promoter (Amersham Biosciences, Piscataway, NJ). The sequence of the construct was confirmed by DNA sequencing. The plasmid was transformed into Escherichia coli host strain BL21. A single colony was used to inoculate $5 \mathrm{ml}$ of 
lysogeny broth medium containing $100 \mu \mathrm{g} / \mathrm{ml}$ ampicilin and incubated overnight at $37^{\circ} \mathrm{C}$ with vigorous shaking. The culture was then diluted 1:100 into fresh 2YT medium with 100 $\mu \mathrm{g} / \mathrm{ml}$ ampicilin and grown at $37^{\circ} \mathrm{C}$ with shaking until $\mathrm{A}_{600}$ reached 1.0. Expression of the fusion protein was then initiated by adding a lactose analog IPTG $(0.2 \mathrm{mM})$, and the cells were grown at $25^{\circ} \mathrm{C}$ for another $6 \mathrm{~h}$ with vigorous shaking. Cell pellets were harvested with centrifugation at $6,000 \mathrm{rpm}, 4^{\circ} \mathrm{C}$ for $10 \mathrm{~min}$ (Beckman JA20 rotor), and cell pellets were frozen at $-20^{\circ} \mathrm{C}$ until used. The pellets were then suspended in ice-cold binding buffer (in $\mathrm{mM}$ ): $140 \mathrm{NaCl}, 2.7 \mathrm{KCl}, 10 \mathrm{Na}_{2} \mathrm{HPO}_{4}, 1.8 \mathrm{KH}_{2} \mathrm{PO}_{4}, \mathrm{pH} 7.3$, containing $0.3 \mathrm{mM}$ phenylmethylsulfonyl fluoride, $10 \mathrm{mM}$ DTT, $100 \mu \mathrm{g} / \mathrm{ml}$ lysozyme, and a cocktail of protease inhibitors (Roche Applied Science, Indianapolis, IN). After 1-h incubation on ice, cells were sonicated for $30 \mathrm{~s}$ for 5-6 times and solubilized in $1 \%$ Triton X-100. The lysate was centrifuged at $15,000 \mathrm{~g}$ for $10 \mathrm{~min}$ at $4^{\circ} \mathrm{C}$, and the supernatant was transferred to a fresh container. The GST-PMAT NH $\mathrm{N}_{2}$-terminal fusion protein in the supernatant was purified using a GSTrap FF 5-ml column prepacked with glutathione sephorose $4 \mathrm{~B}$, according to the manufacturer's instructions (Amersham Biosciences). Briefly, the column was preequilibrated with binding buffer, and the sample was passed through at a constant rate of $1 \mathrm{ml} / \mathrm{min}$ using a perfusion pump system (BioCAD). After being washed with binding buffer, the GST fusion protein bound to the sephorose resin was eluted with $50 \mathrm{mM}$ Tris . $\mathrm{HCl}$ buffer containing $10 \mathrm{mM}$ reduced glutathione ( $\mathrm{pH}$ 8.0). It was further purified on $12 \%$ SDS-PAGE, and electro-eluted from the polyacrylamide gel slice. The purified protein was sequenced by tandem mass spectrometry on a Q-TOF APi US instrument (Waters, Beverly, MA), and the peptide sequence matched $100 \%$ of the expected sequence of $\mathrm{PMAT} \mathrm{NH}_{2}$ terminus.

\section{Production of polyclonal antibody}

Polyclonal antisera were produced commercially by immunizing rabbits with purified GSTPMAT $\mathrm{NH}_{2}$-terminal fusion protein using standard protocols (Invitrogen, Carlsbad, CA). The antibody was produced in a specific pathogen-free (SPF) animal facility that strictly adheres to National Institutes of Health and U. S. Department of Agriculture guidelines for animal use. Antiserum with the highest ELISA titer toward the purified antigen was used in this study.

\section{PMAT expression in MDCK cells}

PMAT cDNA was obtained and expressed in MDCK cells, as described previously (5). In brief, PMAT cDNA, isolated from a human kidney cDNA library, was subcloned into the pcDNA3 vector (Invitrogen) and transfected into MDCK cells by liposome-mediated transfection (lipofectamine, Invitrogen). A stably transfected cell line was obtained by G418 selection and maintained in DMEM with L-glutamine containing $10 \%$ fetal bovine serum and $200 \mu \mathrm{g} / \mathrm{ml}$ of G418.

\section{Western blot analysis}

For protein extraction, nontransfected, vector- or PMAT-transfected MDCK cells were scraped from the culture plates, washed three times with cold Dulbecco's PBS at $4^{\circ} \mathrm{C}$. Cell pellets were resuspended and incubated on ice for $1 \mathrm{~h}$ in a lysis buffer $(50 \mathrm{mM} \mathrm{Tris} \cdot \mathrm{HCl}$, pH 7.4) containing $1 \%$ Nonidet P-40, $20 \mu \mathrm{g} / \mathrm{ml}$ phenylmethylsulfonyl fluoride, and protease inhibitor cocktail (Roche Applied Science, Indianapolis, IN). The lysates were centrifuged at $13,000 \mathrm{~g}$ at $4^{\circ} \mathrm{C}$ for $10 \mathrm{~min}$ to remove cell debris. The protein contents from the supernatant were quantified using a BCA protein assay (Pierce Biotechnology, Rockford, IL). An aliquot of the supernatant ( $20 \mu \mathrm{g}$ protein) was boiled for $5 \mathrm{~min}$, electrophoresized on $7.5 \%$ SDS polyacrylamide gels, and electrophoretically transferred to a polyvinylidene difluoride membrane (Millipore, Bedford, MA) using a standard Western blot analysis procedure (17). The membrane was blocked with 5\% (wt/vol) nonfat dry milk powder (Bio-Rad 
Laboratories, Hercules, CA) in PBS for $1 \mathrm{~h}$ and incubated with the PMAT polyclonal antibody diluted 1:1,600 in $1 \%$ milk in PBS for $2 \mathrm{~h}$ after being washed three times with PBS containing $0.1 \%$ Tween- 20 . The blot was then incubated with horseradish peroxidase conjugated goat anti-rabbit IgG (1:20,000 dilution). Immunoreactive proteins were detected by chemiluminescence using supersignal west pico reagent (Pierce Biotechnology) followed by autoradiography. To detect PMAT expression in human kidney, commercial blots containing human kidney whole lysates ( $20 \mu \mathrm{g} / \mathrm{lane}$ ) were purchased from Imgenex (San Diego, CA). Immunodetection was performed with the PMAT antibody, as described above. Control blots included detection with prebleed rabbit serum or antibody preabsorbed with the purified GST-PMAT $\mathrm{NH}_{2}$-terminal fusion protein. To detect GAPDH, an internal control, the same blot used for PMAT detection was stripped using restore Western blot analysis stripping buffer from Pierce Biotechnology and incubated with mouse monoclonal anti-GAPDH antibody $(1: 1,000)$ (Imgenex Biotechnology), followed by horseradish peroxidase-conjugated goat anti-mouse $\operatorname{IgG}$ (1:20,000 dilution).

\section{Immunocytochemistry}

For immunostaining of PMAT in undifferentiated MDCK cells, cells were grown 3 days in four-well Lab-Tek borosilicated coverglass chambers (Nalge Nunc International, Naperville, IL). Cells were rinsed twice with PBS and fixed for $30 \mathrm{~min}$ at room temperature with $4 \%$ (vol/vol) paraformaldehyde. Cells were then rinsed three times with PBS and incubated in $50 \mathrm{mM} \mathrm{NH}_{4} \mathrm{Cl}$ in PBS for 15 min to quench the fixative. Cells were then permeabilized with $0.2 \%$ Triton X-100 in PBS for 10 min. Potential sites for nonspecific antibody binding were blocked by a 90-min incubation with a blocking buffer (10\% FBS, $0.1 \%$ Triton X-100 in PBS). The cells were incubated with the primary rabbit anti-PMAT antibody (1:200 dilution in blocking buffer) for $1 \mathrm{~h}$, washed three times with PBS containing $0.05 \%$ Tween 20 , and incubated 30 min with a secondary Alexa Fluor 488 conjugated goat anti-rabbit IgG (1:1,000 in blocking buffer) (Molecular Probes, Eugene, OR) in the dark. The cells were then washed three times with PBS containing $0.05 \%$ Tween 20. For nonpermeabilized cells, the blocking and washing buffers contained no detergent. The cell nuclei were counterstained with Topro-3 (Molecular Probes). The cells in the chamber were observed and photographed by a Leica SP1/MP confocal microscope with inverted lens. To localize PMAT protein in polarized MDCK cells, 1 million cells were seeded on six-well polycarbonate filter inserts with $0.4-\mu \mathrm{m}$ pore size (Costar, Cambridge, MA) and cultured for 10-12 days. Before each experiment, the integrity of the monolayer was assessed by transepithelial electrical resistance (TEER) measured by millicell-ERS (Millipore). Cells were permeabilized with $0.2 \%$ Triton X-100 in PBS containing $0.1 \mathrm{mM} \mathrm{CaCl}_{2}$ and $1 \mathrm{mM}$ $\mathrm{MgCl}_{2}$. Immunostaining of polarized MDCK cells was performed by adding the PMAT antibody to both apical and basolateral chambers and developed using the same procedures as described above except that all PBS buffers contained $0.1 \mathrm{mM} \mathrm{CaCl}_{2}$ and $1 \mathrm{mM} \mathrm{MgCl}$. The filters were then removed and mounted on slides. Cells were first imaged in the $x-y$ plane followed by the corresponding vertical scanning in the $z$ plane using a Leica Spectral confocal microscope.

\section{Yellow fluorescent protein construction and fluorescence microscopy}

To express yellow fluorescent protein (YFP)-tagged PMAT in MDCK cells, PMAT cDNA was subcloned into the pEYFP-C1 vector (Clontech, Mountain View, CA) and stably transfected into MDCK cells as described before (5). Empty pEYFP-C1 vector was transfected into MDCK cells as a control. YFP-positive cells were purified using the FACS Vantage S.E. flow cytometry sorter (BD Biosciences, San Jose, CA). Cells were seeded on polycarbonate filter inserts and cultured for 10-12 days. Living cells expressing YFP or YFP-tagged PMAT were observed directly from the filter inserts mounted on slides using a Leica Spectral confocal microscope. 


\section{Transport assays}

Vector- or PMAT-transfected cells were plated in 24-well plates $\left(\sim 10^{5}\right.$ cells $\left./ \mathrm{ml}\right)$ and allowed to grow for 2 days to reach 95-100\% confluence. Cells were rinsed with Krebs-RingerHenseleit (KRH) buffer (pH 7.4) and then preincubated in KRH buffer (pH 7.4) for $10 \mathrm{~min}$ at $37^{\circ} \mathrm{C}$. Transport assays were performed at $37^{\circ} \mathrm{C}$ for 1 min by incubating cells in $\mathrm{KRH}$ buffer containing $\left[{ }^{3} \mathrm{H}\right]$-labeled $\mathrm{MPP}^{+}$at $\mathrm{pH} 6.6$ buffered by 2 - $(N$-morpholino)ethanesulfonic acid, pH 7.4 and 8.2 (buffered by HEPES). After incubation, uptake was terminated by aspirating the reaction mixture and washing cells three times with ice-cold KRH buffer $(\mathrm{pH}$ 7.4). Cells were then solubilized with $0.5 \mathrm{ml}$ of $1 \mathrm{~N} \mathrm{NaOH}$, and neutralized with $0.5 \mathrm{ml}$ of 1 $\mathrm{N} \mathrm{HCl}$. One-half milliliter of the cell lysates was used for quantifying radioactivity by liquid scintillation counting, and $25 \mu \mathrm{l}$ were used for protein determination using a BCA assay. To determine the effect of carbonyl cyanide $p$-trifluormethoxyphenylhydrazone (FCCP) on PMAT-mediated $\left[{ }^{3} \mathrm{H}\right] \mathrm{MPP}^{+}$uptake, cells were preincubated in KRH buffer (pH 7.4) with FCCP $(50 \mu \mathrm{M})$, valinomycin $(10 \mu \mathrm{M})$, or FCCP $(50 \mu \mathrm{M})$ and valinomycin $(10 \mu \mathrm{M})$ for 10 $\mathrm{min}$ at $37^{\circ} \mathrm{C}$. Cells were then incubated at $37^{\circ} \mathrm{C}$ for $1 \mathrm{~min}$ in $\mathrm{KRH}$ buffer at $\mathrm{pH} 6.6$ or $\mathrm{pH} 7.4$ containing $1 \mu \mathrm{M}$ of $\left[{ }^{3} \mathrm{H}\right] \mathrm{MPP}^{+}$and FCCP $(50 \mu \mathrm{M})$, or valinomycin $(10 \mu \mathrm{M})$, or FCCP $(50$ $\mu \mathrm{M})$ and valinomycin $(10 \mu \mathrm{M})$. After incubation, samples were washed and assayed as described above. To determine the effect of nucleoside analogs on PMAT-mediated organic cation uptake, cells were preincubated in $\mathrm{KRH}$ buffer $\left(\mathrm{pH}\right.$ 7.4) for $10 \mathrm{~min}$ at $37^{\circ} \mathrm{C}$. Cells were then incubated at $37^{\circ} \mathrm{C}$ for $1 \mathrm{~min}$ in KRH buffer containing $1 \mu \mathrm{M}$ of $\left[{ }^{3} \mathrm{H}\right] \mathrm{MPP}^{+}$or $\left[{ }^{3} \mathrm{H}\right]$ histamine in the absence (control) or presence of $1 \mathrm{mM}$ of unlabeled compounds. After incubating $1 \mathrm{~min}$ for $\left[{ }^{3} \mathrm{H}\right] \mathrm{MPP}^{+}$or $5 \mathrm{~min}$ for $\left[{ }^{3} \mathrm{H}\right]$ histamine, cells were rinsed three times with ice-cold KRH buffer, and samples were assayed as described above.

\section{Data analysis}

All experiments were performed in triplicate and repeated three to four times. The PMATspecific uptake was calculated by subtracting the transport activity in vector-transfected cells. Data were expressed as means (SD). Statistical significance was determined by Student's $t$-test. For Michaelis-Menten studies, data were fit to the equation $V=V_{\max }[S] /\left(K_{\mathrm{m}}\right.$ $+[S]$ ) using Kaleidagraph Version 3.6 (Synergy Software, Reading, PA), where $V$ is the transport rate and $[S]$ is the substrate concentration. Kinetic parameters were determined by nonlinear least-squares regression fitting as described previously $(4,5)$.

\section{RESULTS}

\section{Generation and characterization of an anti-PMAT polyclonal antibody}

The $\mathrm{NH}_{2}$ terminus of human PMAT (66 aa) was predicted to reside intracellularly (Fig. 1A). We chose this region for antibody development because it is highly hydrophilic and PMAT specific $(5,8)$. The $\mathrm{NH}_{2}$-terminal 66 amino acid residues in PMAT were fused to the $\mathrm{COOH}$ terminus of a parasite GST protein, and the resulting fusion protein was overexpressed in $E$. coli. The fusion protein was purified, and its sequence was verified by tandem mass spectrometry. The purified fusion protein was then used as the antigen to produce a polyclonal rabbit anti-PMAT antibody using standard methods. The specificity of the antibody was tested in PMAT-expressing MDCK cells by Western blot analysis and immunocytochemistry. Western blot analysis was performed on whole cell lysates prepared from untransfected, vector- and PMAT-transfected MDCK cells (Fig. 1B). MDCK cells expressing PMAT showed a strong band of immunoreactivity with an apparent molecular weight of $\sim 55 \mathrm{kDa}$, which is consistent with the calculated molecular mass of PMAT (58 $\mathrm{kDa})$. This band was absent in untransfected MDCK cells and in cells transfected with the empty vector. Two faint bands with higher molecular weight ( 110 kDa and $\sim 180 \mathrm{kDa})$ were also observed in PMAT-expressing cells, which may represent a higher order of oligomerization state of this transporter. In addition, two faint nonspecific bands were seen 
in both vector- and PMAT-transfected cells. These data suggest that the polyclonal antibody generated toward the $\mathrm{NH}_{2}$ terminus of PMAT is highly reactive to the human PMAT protein. To test the usefulness of this antibody for immunostaining, immunocytochemistry was performed in vector- and PMAT-transfected MDCK cells. As shown in Fig. 1D, permeabilized, PMAT-expressing cells showed strong immunofluorescence on their plasma membranes. This specific cell surface staining was absent in permeabilized, vectortransfected cells or permeabilized PMAT-expressing cells incubated with prebleed rabbit antisera (Fig. 1, $C$ and $E$ ). Moreover, if nonpermeabilized cells were used, no specific membrane staining was observed for PMAT-expressing cells incubated with the anti-PMAT antibody (Fig. $1 F$ ), suggesting that the antibody recognizes an intracellular domain of the PMAT protein. Because the antibody was raised against the $\mathrm{NH}_{2}$-terminal 66 residues, this staining pattern also suggests that the $\mathrm{NH}_{2}$ terminus of PMAT indeed resides in the cytoplasm side, as we had previously predicted (5).

\section{PMAT protein is present in the human kidney}

To determine whether PMAT protein is present in the human kidney, immunoblotting was carried out with the anti-PMAT antibody using lysates from human kidney homogenate. A single, strong band with an apparent molecular weight of $\sim 55 \mathrm{kDa}$ was observed, consistent with the expected molecular mass of PMAT (58 kDa) (Fig. 2). This band disappeared when immunoblotting was carried out with prebleed antiserum (data not shown) or with the antiPMAT antibody preabsorbed with the fusion protein antigen (Fig. 2). These data clearly demonstrated that the PMAT protein is expressed in the human kidney.

\section{PMAT is localized to the apical membrane of polarized MDCK cells}

Our Western blot analysis clearly showed that the PMAT protein is expressed in the human kidney. However, efforts to directly localize PMAT in cryopreserved human kidney tissue sections with this antibody were unsuccessful, because of a high level of background staining. Therefore, we used MDCK cells as a model to study the membrane localization of PMAT in renal epithelial cells. PMAT-expressing MDCK cells were cultured on polycarbonate filter inserts for 10-12 days, and immunoreactivity was analyzed by incubating antibodies in both apical and basolateral chambers. As shown in Fig. 3A, the PMAT immunoreactivity was primarily confined to the villous apical membranes of polarized MDCK cells. Staining of the basolateral membranes was faint and nonspecific. As the antibody in the upper chamber was in free contact with the apical membrane, whereas the antibody in the lower chamber needed to cross the filter insert to gain access to the basolateral membrane, the predominant staining of apical membrane could be due to unequal antibody access to the two sides of the membranes. To preclude this possibility, an additional method with fluorescent protein imaging was used. MDCK cells were transfected with a cDNA construct, in which YFP was tagged to the $\mathrm{NH}_{2}$ terminus of PMAT. Cells were cultured on polycarbonate filter inserts, and living cells expressing YFP or YFP-tagged PMAT were observed directly by fluorescence confocal microscopy. As shown in Fig. 3B, YFP-tagged PMAT is predominantly routed to the apical membrane of polarized MDCK cells. Cells transfected with the YFP only showed diffuse cytoplasmic fluorescence (Fig. $3 C$ ). Together, these data demonstrated that PMAT protein is targeted to the apical membranes of differentiated kidney epithelial cells.

\section{Effect of extracellular pH on PMAT-mediated $\left[{ }^{3} \mathrm{H}\right] \mathrm{MPP}+$ uptake}

The above data suggested that PMAT protein is expressed in the human kidney and is likely to be present at the apical membrane of renal epithelial cells. As the luminal $\mathrm{pH}$ in the kidney is acidic, we next examined the effect of $\mathrm{pH}$ on the initial rates of PMAT-mediated organic cation uptake using a permanently charged substrate $\mathrm{MPP}^{+}$. As shown in Fig. 4, uptake of $\left[{ }^{3} \mathrm{H}\right] \mathrm{MPP}^{+}(1 \mu \mathrm{M})$ at $1 \mathrm{~min}$ in PMAT-transfected cells is substantially increased 
by lowering the extracellular $\mathrm{pH}$ from 7.4 to 6.6 . Raising extracellular $\mathrm{pH}$ from 7.4 to 8.2 abolished uptake. Similar stimulatory effects by acidic $\mathrm{pH}$ were also observed for other PMAT substrates, such as dopamine and histamine (data not shown). To determine the effect of extracellular $\mathrm{pH}$ on the kinetics of $\mathrm{MPP}^{+}$transport by PMAT, initial rates of $\left[{ }^{3} \mathrm{H}\right] \mathrm{MPP}^{+}$at $\mathrm{pH} 7.4$ and $\mathrm{pH} 6.6$ were evaluated at substrate concentrations ranging from 0 to $800 \mu \mathrm{M}$ (Fig. 5). One-minute uptake was chosen because it is within the linear range of uptake at both $\mathrm{pH}$ conditions (data not shown). Because Eadie-Hofstee plots showed a straight line at both $\mathrm{pH}$ conditions, the kinetic parameters were determined by nonlinear least-squares regression by fitting the data to the Michaelis-Menten equation. The calculated apparent $K_{\mathrm{m}}$ and $V_{\max }$ values were $104 \pm 18 \mu \mathrm{M}$ and $1,454 \pm 77 \mathrm{pmol} / \mathrm{mg}$ protein $/ \mathrm{min}$, respectively, at $\mathrm{pH}$ 7.4. At $\mathrm{pH} 6.6$, the $K_{\mathrm{m}}$ and $V_{\max }$ values were $123 \pm 23 \mu \mathrm{M}$ and 5,712 \pm $349 \mathrm{pmol} \cdot \mathrm{mg}$ protein ${ }^{-1} \cdot \mathrm{min}^{-1}$, respectively. The $K_{\mathrm{m}}$ values are not significantly different at the two $\mathrm{pH}$ conditions. However, the $V_{\max }$ at $\mathrm{pH} 6.6$ is fourfold higher than that of $\mathrm{pH}$ 7.4. The predominant $\mathrm{pH}$ effect on $V_{\mathrm{max}}$, but not $K_{\mathrm{m}}$, is also evident in the Eadie-Hofstee plot (Fig. 5B).

To examine whether the increase in $\mathrm{MPP}^{+}$transport by PMAT at $\mathrm{pH} 6.6$ was due to substrate coupling with the proton gradient across cell membranes, the effect of the proton ionophore, FCCP, on PMAT-mediated $\mathrm{MPP}^{+}$uptake was examined. To exclude the possible effect of FCCP-elicited change in membrane potential, valinomycin was used to clamp the membrane potential. At extracellular $\mathrm{pH}$ of 6.6 , valinomycin alone only moderately reduced $\mathrm{MPP}^{+}$uptake (Fig. 6A). In contrast, FCCP alone, or in the presence of valinomycin, dramatically reduced PMAT-mediated $\mathrm{MPP}^{+}$uptake. At an extracellular $\mathrm{pH}$ of 7.4, FCCP alone or with valinomycin exhibited much less pronounced effects on PMAT-mediated $\mathrm{MPP}^{+}$uptake (Fig. $6 B$ ). These data strongly suggest that the apparent stimulatory effect of proton on PMAT-mediated organic cation transport is perhaps due to transporter coupling with the inwardly directed proton gradient.

\section{Effect of nucleoside analogs on PMAT-mediated MPP+ uptake}

Previous work by Nelson and colleagues (3) described a nucleoside-sensitive organic cation transporter in opossum kidney $(\mathrm{OK})$ cells that appeared to be different from the OCTs. In particular, organic cation transport by this carrier is sensitive to inhibition by a number of nucleoside analogs exemplified by the deoxyadenosine analog, deoxytubercidin (7-deaza-2'deoxyadenosine) (3). To test whether PMAT could represent the nucleoside-sensitive organic cation transporter, we examined the inhibitory effect of several nucleoside analogs on PMAT-mediated uptake of a high-affinity substrate, $\operatorname{MPP}^{+}\left(K_{\mathrm{m}}=33 \mu \mathrm{M}\right)$, and a lowaffinity substrate, histamine $\left(K_{\mathrm{m}}=10,471 \mu \mathrm{M}\right)(4,5)$. At $1 \mathrm{mM}$ and under normal $\mathrm{pH}$, adenosine, 2-chlorodeoxyadensine and deoxytubercidin significantly inhibited PMATmediated $\left[{ }^{3} \mathrm{H}\right] \mathrm{MPP}^{+}(1 \mu \mathrm{M})$ uptake (Fig. $\left.7 A\right)$. Under the same conditions, other nucleoside analogs, including AraA, AraC, AZT, ddC, ddI, and ddT did not exhibit significant inhibitory effects on PMAT-mediated $\left[{ }^{3} \mathrm{H}\right] \mathrm{MPP}^{+}$uptake. Similarly, PMAT-mediated $\left[{ }^{3} \mathrm{H}\right]$ histamine uptake was significantly inhibited by adenosine and CdA but not by other nucleoside analogs (Fig. 7B).

\section{DISCUSSION}

PMAT (or ENT4) was recently cloned and characterized in our laboratory $(4,5)$. By gene ontology, this transporter belongs to the mammalian ENT family (SLC29), which consists of four isoforms in humans and rodents $(1,8)$. ENT1 and ENT2 are expressed on plasma membranes of mammalian cells and exclusively transport nucleosides and their structural analogs $(1,8)$. ENT3 is an intracellular nucleoside transporter (2). Our previous work demonstrated that except for minor activity toward adenosine, PMAT does not significantly transport nucleosides and their structural analogs (5). Instead, it mediates $\mathrm{Na}^{+}$-independent, 
electrogenic transport of organic cations, including monoamine neurotransmitters (5). The functional properties of PMAT are remarkably similar to the OCTs, to which PMAT exhibits no significant sequence homology $(4,5)$. Given that PMAT transports organic cations and that mRNA transcripts of PMAT were found in the human kidney $(4,5)$, it is possible that this transporter may also play a role in the renal handling of organic cations. In this study, we explored the role of PMAT in renal transport of organic cations by determining the protein expression and membrane localization of PMAT in kidney cells. We also further explored the transport mechanism of PMAT by analyzing the effect of proton and proton gradient, an important driving force for solute transport in the kidney, on PMATmediated organic cation transport.

To understand the tissue and cellular localization of PMAT, it is essential to obtain a highly reactive and specific anti-PMAT antibody. In the present study, we used a fusion protein approach to generate a polyclonal antibody directed toward the long and hydrophilic $\mathrm{NH}_{2}-$ terminal 66 residues of human PMAT. This region is highly specific to PMAT, as it is most divergent from other SLC29 members (i.e., ENT1-3) $(2,5,8)$. The antibody generated toward the $\mathrm{NH}_{2}$ terminus of PMAT worked well in both Western blot and immunocytochemistry in PMAT-expressing MDCK cells (Fig. 1). Importantly, the antibody only generated membrane staining when the plasma membranes were permeabilized, suggesting that it recognizes an intracellular antigen. This is consistent with our predicted membrane topology of PMAT, in which the $\mathrm{NH}_{2}$ terminus of the transporter protein resides intracellularly, while the $\mathrm{COOH}$ terminus faces the outside. Using this antibody, we found that a single strong band corresponding to the molecular weight of PMAT could be easily detected by immunoblotting in human kidney tissue homogenate (Fig. 2). The band disappeared if the antibody was preabsorbed with the fusion protein antigen, upon which the antibody was generated. These data clearly demonstrated that the full-length PMAT protein is expressed in the human kidney.

Unfortunately, efforts to directly determine the segmental and membrane localization of PMAT protein in human nephrons were not successful. Immunohistochemical studies in cryopreserved human kidney tissue sections with this antibody showed high background staining of both renal tubules and glomeruli. Although we occasionally observed prominent staining of apical membranes in some slides, the overall data were inconclusive and not sufficient for drawing definitive conclusions. The reason for the high background staining is unknown but could be due to the impurity of this polyclonal antibody. However, efforts to further purify this antibody with fusion protein antigen-packed columns failed, as the antibody lost reactivity after elusion from the column. Antibodies suitable for immunohistochemical analysis are currently being pursued to definitively determine the nephron and cellular localization of PMAT in the human kidney. We then turned to an indirect method to infer the membrane localization of PMAT protein using MDCK cells stably expressing human PMAT. MDCK is a well-characterized renal tubular cell line and has been used to accurately predict the membrane localization of many membrane transporters in the kidney, including the OCTs and the ENTs $(9,11,15)$. In welldifferentiated MDCK cells, immunostaining of untagged PMAT and confocal imaging of YFP-tagged PMAT clearly demonstrated that PMAT protein is targeted to the apical membranes of these polarized kidney cells, suggesting that PMAT may be involved in luminal transport of organic cations. The apical localization of PMAT in polarized kidney cells is different from that of OCT1 and OCT2, which are localized to the basolateral membranes in MDCK cells and renal proximal tubules $(7,15,18)$. These data suggest that although PMAT and OCTs share a large substrate overlap in transporting organic cations (4), they play different physiological roles in organic cation transport in the kidney. The apical membrane localization of PMAT is also different from that of ENT1 and ENT2, which are localized in the basolateral membranes of polarized epithelial cells, including 
transfected MDCK cells $(8,9,11)$. The unique apical membrane localization of PMAT in polarized epithelial cells provided further evidence that this transporter is distinct from other ENTs and has evolved to play a different physiological role in the body.

Our localization studies suggest that PMAT is present in the apical membranes of renal epithelial cells. In the kidney, luminal $\mathrm{pH}$ in the renal tubules is acidic ( $\mathrm{pH} \sim 6.5$ ), generating an inwardly directed proton gradient from lumen to the cytoplasm of tubular cells ( $\mathrm{pH} ~ 7.4$ ). This proton gradient is used by several renal cotransporters (e.g., the proton/peptide cotransporters PepT1 and 2) and antiporters (e.g., the proton/organic cation exchanger MATE1) as the major driving force for active solute transport. We previously showed that PMAT-mediated organic cation transport is $\mathrm{Na}^{+}$independent and driven by the inside negative membrane potential (5). To further explore the transport mechanism of PMAT, we examined the effect of extracellular $\mathrm{pH}$ on the initial rates of PMAT-mediated MPP $\mathrm{Mptake}^{+}$ As shown in Fig. 4, PMAT-mediated $\mathrm{MPP}^{+}$uptake is sensitive to extracellular $\mathrm{pH}$ changes, favoring acidic over basic conditions. These observations are different from the OCTs (OCT2 and OCT1), which are also $\mathrm{pH}$ sensitive but appear to favor basic over acidic $\mathrm{pH}$ $(6,16,18)$. Kinetic analysis revealed that the increase in organic cation transport activity of PMAT at acidic $\mathrm{pH}$ was mainly due to an increase in $V_{\max }$, as opposed to a change in $K_{\mathrm{m}}$ (Fig. 5). Because a permanently charged substrate (i.e., $\mathrm{MPP}^{+}$) is used in these studies and the $\mathrm{pH}$ effect was also observed under voltage-clamp conditions, such stimulatory effects are unlikely to be caused by a $\mathrm{pH}$ effect on substrate fractional protonation or indirect changes in membrane potential due to proton diffusion. A direct effect of proton or proton gradient on the transporter itself must have occurred. To further explore the mechanism of $\mathrm{pH}-$ dependent transport, the effect of the proton ionophore, FCCP, on PMAT-mediated $\mathrm{MPP}^{+}$ uptake was examined. FCCP alone, or in the presence of valinomycin, drastically reduced PMAT-mediated MPP ${ }^{+}$uptake at extracellular $\mathrm{pH}$ of 6.6 (Fig. 6). Such dramatic effect was not observed at extracellular $\mathrm{pH}$ of 7.4. These observations are consistent with a proton/ organic cation cotransport mechanism, in which substrate uptake is coupled to proton influx.

Because PMAT-mediated organic cation uptake is favored by the physiological inside negative membrane potential (5) and can be further stimulated by acidic extracellular $\mathrm{pH}$ (Figs. 4-6), a luminal membrane localization of this transporter in renal epithelial cells would suggest a role of organic cation uptake from the tubular lumen (i.e., reabsorption). Although it is known that secretion is the predominant direction of organic cation flux in the kidney, a number of reabsorptive processes have also been described $(12,20,22)$. For example, in rabbit renal brush border membrane vesicles, at least two organic cation transporters have been described that appear to function in the reabsorptive direction $(12,20)$. These transporters may serve to reabsorb some endogenous cations, such as dopamine and choline. PMAT may fulfill such a role in the kidney. Interestingly, Chen et al. (3) described a nucleoside-sensitive organic cation transporter in opossum kidney (OK) cells that is different from the OCTs. In particular, organic cation transport by this carrier is sensitive to inhibition by a number of nucleoside analogs, including deoxytubercidin, ddC, and AZT. We thus examined the effect of several nucleoside analogs on PMAT-mediated organic cation uptake at normal $\mathrm{pH}$. Among the nucleoside analogs tested, only adenosine and adenosine analogs (e.g., 2-chlorodeoxyadensine, deoxytubercidin) significantly inhibited PMAT-mediated $\left[{ }^{3} \mathrm{H}\right] \mathrm{MPP}^{+}$uptake (Fig. 7). Adenosine and 2chlorodeoxyadensine also inhibited PMAT-mediated uptake of a low-affinity substrate, $\left[{ }^{3} \mathrm{H}\right]$ histamine. These results are consistent with our observations that among the naturally occurring nucleosides, adenosine is the only nucleoside that is recognized and transported by PMAT [(5), and J. Wang et al., unpublished data]. Although deoxytubercidin moderately inhibited PMAT-mediated $\left[{ }^{3} \mathrm{H}\right] \mathrm{MPP}^{+}$uptake, the nucleoside inhibition pattern observed for PMAT was different from that described in OK cells. For example, ddC and AZT potently inhibited the OK cell transporter with $\mathrm{IC}_{50}$ values of 38 and $127 \mu \mathrm{M}$, respectively (3), but 
neither drug had an effect on PMAT at $1 \mathrm{mM}$. Therefore, it is still unknown whether PMAT represents the human form of the nucleoside-sensitive organ cation transporter described in OK cells.

In summary, we have developed a PMAT-specific antibody and provided biochemical evidence that the PMAT protein is present in the human kidney and is likely to be routed to the apical membranes of renal tubular cells. We also demonstrated that PMAT-mediated organic cation uptake is stimulated by acidic extracellular $\mathrm{pH}$, and the transporter may use luminal proton gradient to drive organic cation reabsorption in the kidney.

\section{Acknowledgments}

This study was supported by a National Institutes of Health Grant GM-66233. M. Zhou was supported in part by a predoctoral fellowship from the Eli Lilly and Company Foundation.

\section{References}

1. Baldwin SA, Beal PR, Yao SY, King AE, Cass CE, Young JD. The equilibrative nucleoside transporter family, SLC29. Pflügers Arch. 2004; 447:735-743.

2. Baldwin SA, Yao SY, Hyde RJ, Ng AM, Foppolo S, Barnes K, Ritzel MW, Cass CE, Young JD. Functional characterization of novel human and mouse equilibrative nucleoside transporters (hENT3 and mENT3) located in intracellular membranes. J Biol Chem. 2005; 280:15880-15887. [PubMed: 15701636]

3. Chen R, Pan BF, Sakurai M, Nelson JA. A nucleoside-sensitive organic cation transporter in opossum kidney cells. Am J Physiol Renal Physiol. 1999; 276:F323-F328.

4. Engel K, Wang J. Interaction of organic cations with a newly identified plasma membrane monoamine transporter. Mol Pharmacol. 2005; 68:1397-1407. [PubMed: 16099839]

5. Engel K, Zhou M, Wang J. Identification and characterization of a novel monoamine transporter in the human brain. J Biol Chem. 2004; 279:50042-50049. [PubMed: 15448143]

6. Fujita T, Urban TJ, Leabman MK, Fujita K, Giacomini KM. Transport of drugs in the kidney by the human organic cation transporter, OCT2 and its genetic variants. J Pharm Sci. 2006; 95:25-36. [PubMed: 16307453]

7. Karbach U, Kricke J, Meyer-Wentrup F, Gorboulev V, Volk C, Loffing-Cueni D, Kaissling B, Bachmann S, Koepsell H. Localization of organic cation transporters OCT1 and OCT2 in rat kidney. Am J Physiol Renal Physiol. 2000; 279:F679-F687. [PubMed: 10997918]

8. Kong W, Engel K, Wang J. Mammalian nucleoside transporters. Curr Drug Metab. 2004; 5:63-84. [PubMed: 14965251]

9. Lai Y, Bakken AH, Unadkat JD. Simultaneous expression of hCNT1-CFP and hENT1-YFP in Madin-Darby canine kidney cells. Localization and vectorial transport studies. J Biol Chem. 2002; 277:37711-37717. [PubMed: 12097333]

10. Li M, Anderson GD, Wang J. Drug-drug interactions involving membrane transporters in the human kidney. Expert Opin Drug Metab Toxicol. 2006; 2:505-532. [PubMed: 16859401]

11. Mangravite LM, Xiao G, Giacomini KM. Localization of human equilibrative nucleoside transporters, hENT1 and hENT2, in renal epithelial cells. Am J Physiol Renal Physiol. 2003; 284:F902-F910. [PubMed: 12527552]

12. McKinney TD, Hosford MA. ATP-stimulated tetraethylammonium transport by rabbit renal brush border membrane vesicles. J Biol Chem. 1993; 268:6886-6895. [PubMed: 8463219]

13. Otsuka M, Matsumoto T, Morimoto R, Arioka S, Omote H, Moriyama Y. A human transporter protein that mediates the final excretion step for toxic organic cations. Proc Natl Acad Sci USA. 2005; 102:17923-17928. [PubMed: 16330770]

14. Pritchard JB, Miller DS. Renal secretion of organic anions and cations. Kidney Int. 1996; 49:16491654. [PubMed: 8743470] 
15. Sweet DH, Miller DS, Pritchard JB. Basolateral localization of organic cation transporter 2 in intact renal proximal tubules. Am J Physiol Renal Physiol. 2000; 279:F826-F834. [PubMed: 11053042]

16. Sweet DH, Pritchard JB. rOCT2 is a basolateral potential-driven carrier, not an organic cation/ proton exchanger. Am J Physiol Renal Physiol. 1999; 277:F890-F898.

17. Towbin H, Staehelin T, Gordon J. Electrophoretic transfer of proteins from polyacrylamide gels to nitrocellulose sheets: procedure and some applications. Proc Natl Acad Sci USA. 1979; 76:4350 4354. [PubMed: 388439]

18. Urakami Y, Okuda M, Masuda S, Saito H, Inui KI. Functional characteristics and membrane localization of rat multispecific organic cation transporters, OCT1 and OCT2, mediating tubular secretion of cationic drugs. J Pharmacol Exp Ther. 1998; 287:800-805. [PubMed: 9808712]

19. Wright SH, Dantzler WH. Molecular and cellular physiology of renal organic cation and anion transport. Physiol Rev. 2004; 84:987-1049. [PubMed: 15269342]

20. Wright SH, Wunz TM, Wunz TP. A choline transporter in renal brush-border membrane vesicles: energetics and structural specificity. J Membr Biol. 1992; 126:51-65. [PubMed: 1593612]

21. Wu X, George RL, Huang W, Wang H, Conway SJ, Leibach FH, Ganapathy V. Structural and functional characteristics and tissue distribution pattern of rat OCTN1, an organic cation transporter, cloned from placenta. Biochim Biophys Acta. 2000; 1466:315-327. [PubMed: 10825452]

22. Zhang L, Brett CM, Giacomini KM. Role of organic cation transporters in drug absorption and elimination. Annu Rev Pharmacol Toxicol. 1998; 38:431-460. [PubMed: 9597162]

23. Zhou M, Engel K, Wang J. Evidence for significant contribution of a newly identified monoamine transporter (PMAT) to serotonin uptake in the human brain. Biochem Pharmacol. 2007; 73:147154. [PubMed: 17046718] 


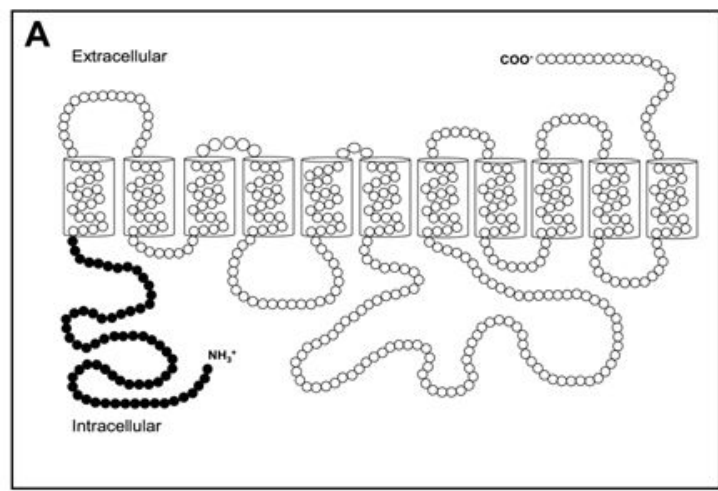

pcDNA3-MDCK Anti-PMAT Ab (1:200)

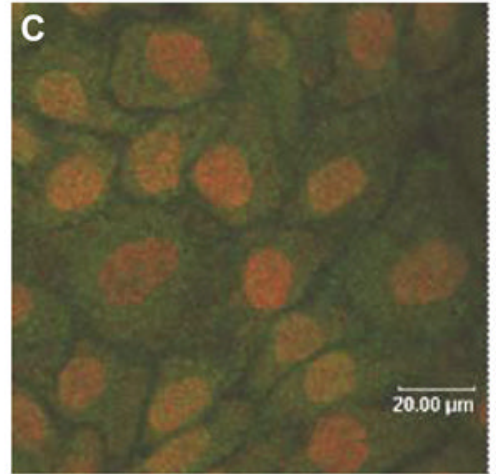

PMAT-MDCK

Pre-bleed serum (1:200)

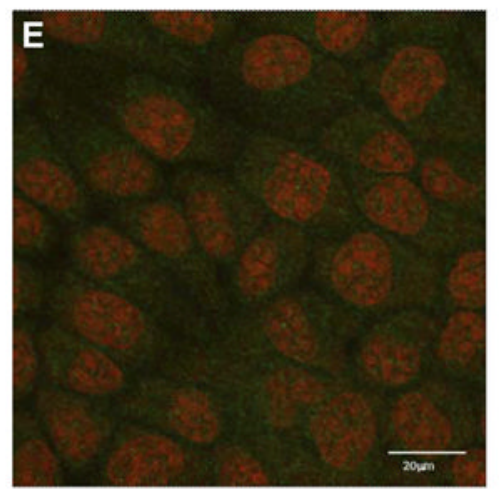

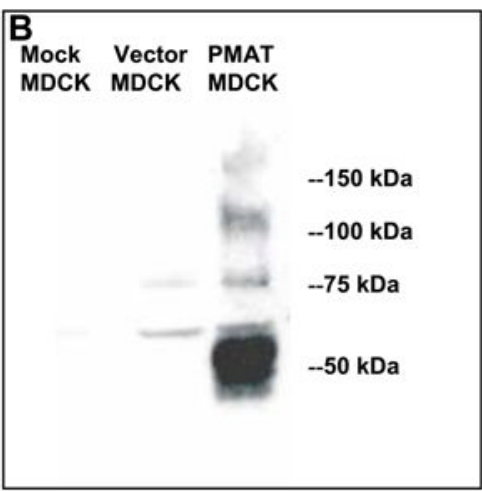

PMAT-MDCK

Anti-PMAT Ab (1:200)

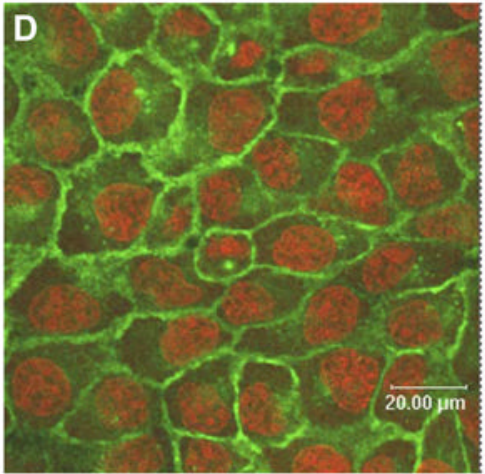

PMAT-MDCK

Anti-PMAT Ab (1:200)

(without permeabilization)

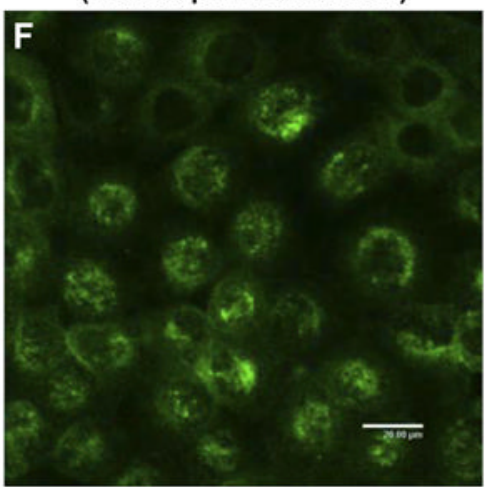

Fig. 1.

Characterization of a polyclonal anti-plasma membrane monoamine transporter (PMAT) antibody. A: proposed membrane topology of PMAT. Antibody was developed toward the $\mathrm{NH}_{2}$-terminal 66 amino acid residues of PMAT (shown in dark). B: Western blot analysis of PMAT protein expressed in Madin-Darby canine kidney (MDCK) cells using the polyclonal antibody (1:1,600 dilution). $C$ : MDCK cells transfected with empty vector (pcDNA3) were permeabilized and stained with anti-PMAT antibody. $D$ : MDCK cells transfected with PMAT were permeabilized and stained with the anti-PMAT antibody. $E$ : MDCK cells transfected with PMAT were permeabilized and stained with prebleed serum. $F$ : MDCK cells transfected with PMAT were stained with anti-PMAT antibody without 
permeabilization. Antibody used in cell staining was at 1:200 dilution. Permeabilization was carried out with $0.2 \%$ Triton X-100. Cell nuclei were counterstained with TO-PRO-3. 


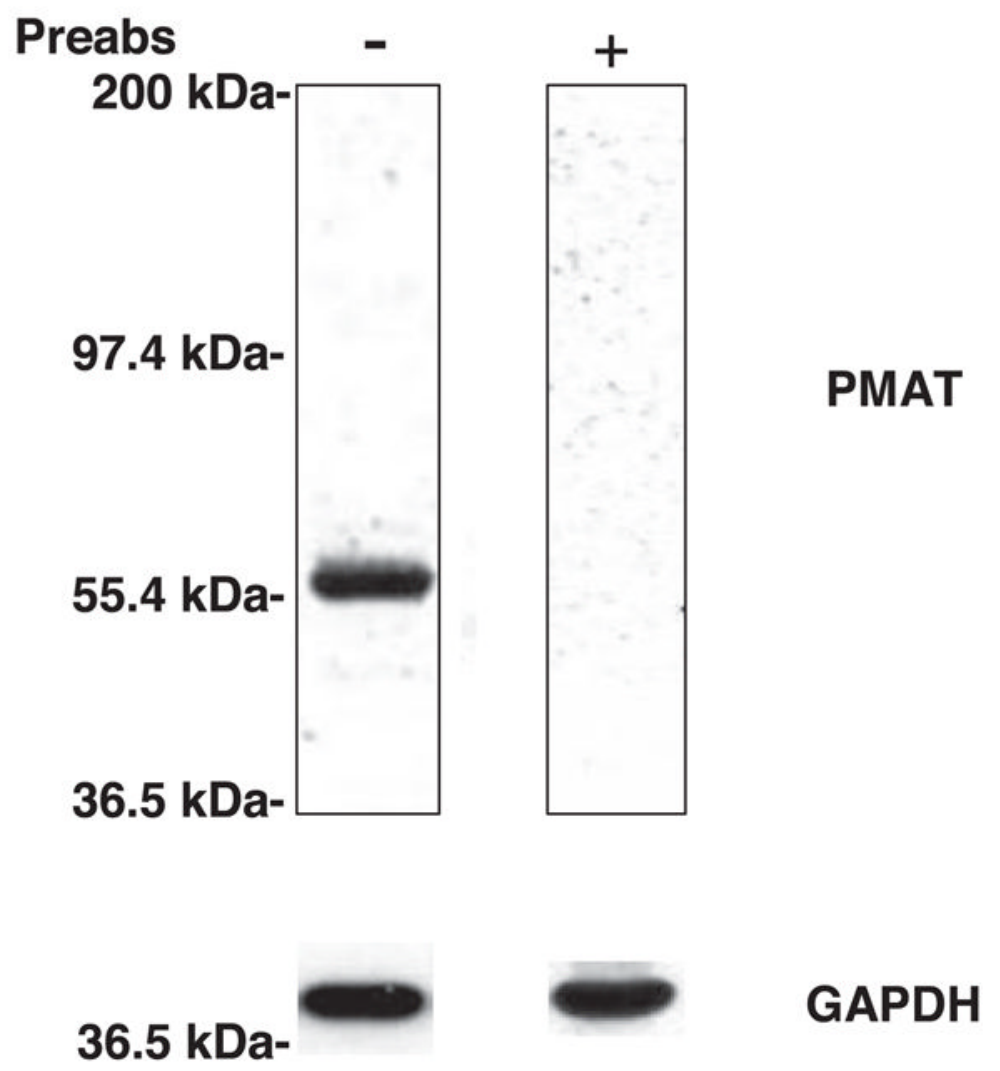

Fig. 2.

Western blot analysis of PMAT expression in human kidney. Immunoblotting was carried out with the anti-PMAT antibody at 1:1,000 dilution. The antiserum for PMAT was either preabsorbed (Preabs.) with (+) or without (-) the purified glutathione $S$-transferase (GST)PMAT $\mathrm{NH}_{2}$-terminal fusion protein. The same blots were stripped and blotted with an antibody against an internal standard, GAPDH. 


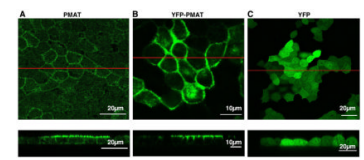

Fig. 3.

Subcellular localization of PMAT or YFP-PMAT in polarized MDCK cells. The cells were cultured on Corning Costar Transwell filters for 10-12 days to allow cell differentiation. The filters were then sliced and loaded on a coverglass slide. MDCK cells stably expressing PMAT were stained with anti-PMAT Ab (1:200) (A). Alternatively, MDCK cells expressing YFP-PMAT $(B)$ and YFP alone $(C)$ were visualized directly with a confocal fluorescence microscope. Cells were imaged in the $x-y$ plane (top). The lines on these images show the $z$ plane for vertical scanning. Bottom: corresponding vertical images. 


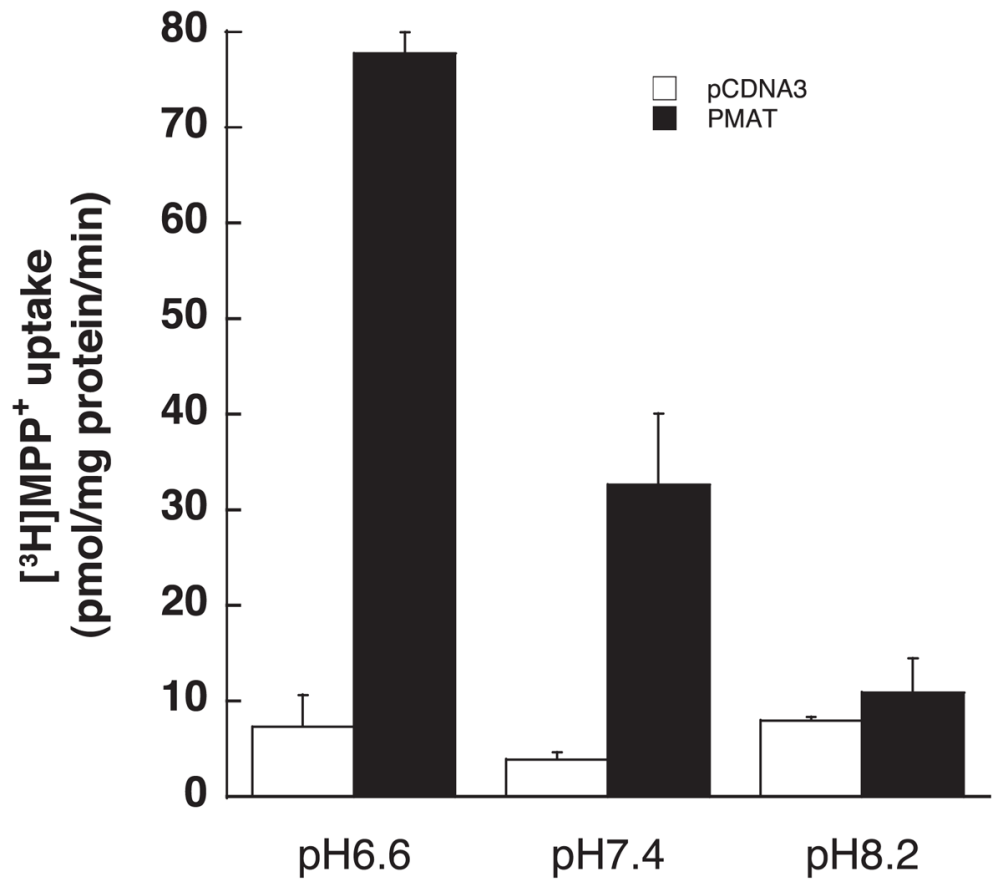

Fig. 4.

Effect of pH on PMAT-mediated $\left[{ }^{3} \mathrm{H}\right] \mathrm{MPP}^{+}$uptake. Vector-transfected cells (open bar) and PMAT-transfected cells (solid bar) were incubated with $1 \mu \mathrm{M}\left[{ }^{3} \mathrm{H}\right] \mathrm{MPP}^{+}$at $\mathrm{pH}$ 6.6, 7.4, and 8.2 for $1 \mathrm{~min}$ at $37^{\circ} \mathrm{C}$. Each bar represents means (SD); $n=3$. 

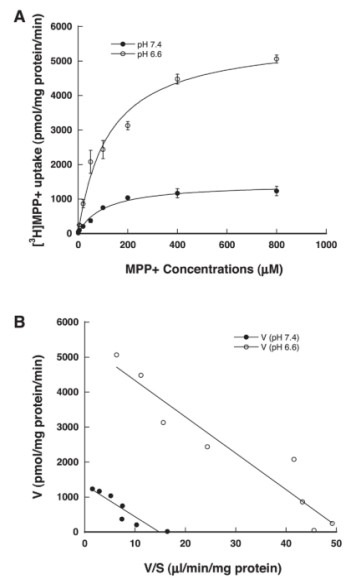

Fig. 5.

Effect of pH on PMAT-mediated $\left[{ }^{3} \mathrm{H}\right] \mathrm{MPP}^{+}$uptake kinetics. A: PMAT-transfected and vector-transfected cells were incubated with varying concentrations of $\mathrm{MPP}^{+}$for $1 \mathrm{~min}$ at $37^{\circ} \mathrm{C}$ under $\mathrm{pH} 6.6$ or $\mathrm{pH}$ 7.4. The PMAT-specific uptake was calculated by subtracting the transport activity in control cells. $B$ : Eadie-Hofstee plots under pH 6.6 and pH 7.4. 

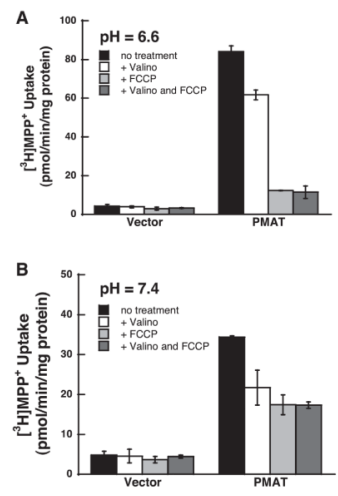

Fig. 6.

Effect of carbonyl cyanide $p$-trifluormethoxyphenylhydrazone (FCCP) on PMAT-mediated $\mathrm{MPP}^{+}$uptake. Vector and PMAT-transfected cells were incubated at $37^{\circ} \mathrm{C}$ with $1 \mu \mathrm{M}$ $\left[{ }^{3} \mathrm{H}\right] \mathrm{MPP}^{+}$for $1 \mathrm{~min}$ in the presence of valinomycin (Valino), FCCP or Valino and FCCP under $\mathrm{pH} 6.6(A)$ or $\mathrm{pH} 7.4(B)$. Each bar represents the means $(\mathrm{SD}) ; n=3$. 

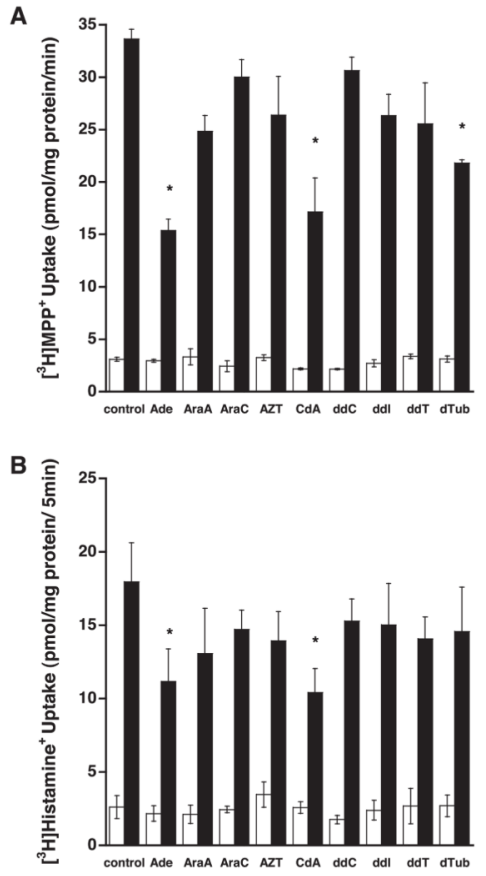

Fig. 7.

Effect of various nucleoside analogs on PMAT-mediated organic cation uptake. Vectortransfected (open bars) and PMAT-transfected cells (solid bars) were incubated at $37^{\circ} \mathrm{C}$ with $1 \mu \mathrm{M}\left[{ }^{3} \mathrm{H}\right] \mathrm{MPP}^{+}$for $1 \min (A)$ or $1 \mu \mathrm{M}\left[{ }^{3} \mathrm{H}\right]$ histamine for $5 \min (B)$ in the absence (control) or presence of various nucleoside analogs at $1 \mathrm{mM}$. Each bar represents the means (SD); $n=$ 3. Ade, adenosine; AraA, 9- $\beta$-D-arabinofuranosyladenine; AraC, 9- $\beta$-D-

arabinofuranosylcytosine; AZT, azidothymidine; CdA, 2-chloro-2'-deoxyadenosine; $\mathrm{ddC}, 2^{\prime}$, 3'-dideoxycytidine; ddI, 2',3'-dideoxyinosine; ddT, 2', 3'-dideoxythymidine; dTub, 2'deoxytubercidin (7-deaza-2'-deoxyadenosine). *Significantly different from control, $P<$ 0.01 . 